\title{
Insights into secondary organic aerosol formed via aqueous-phase reactions of phenolic compounds based on high resolution mass spectrometry
}

\author{
Y. L. Sun ${ }^{1}$, Q. Zhang ${ }^{1}$, C. Anastasio ${ }^{2}$, and J. Sun $^{3}$ \\ ${ }^{1}$ Department of Environmental Toxicology, University of California, Davis, CA 95616, USA \\ ${ }^{2}$ Department of Land, Air and Water Resources, University of California, Davis, CA 95616, USA \\ ${ }^{3}$ College of Architecture and Environment, Sichuan University, Chengdu, Sichuan 610065, China
}

Received: 23 January 2010 - Published in Atmos. Chem. Phys. Discuss.: 5 February 2010

Revised: 1 May 2010 - Accepted: 13 May 2010 - Published: 26 May 2010

\begin{abstract}
Recent work has shown that aqueous-phase reactions of phenolic compounds - phenol $\left(\mathrm{C}_{6} \mathrm{H}_{6} \mathrm{O}\right)$, guaiacol $\left(\mathrm{C}_{7} \mathrm{H}_{8} \mathrm{O}_{2}\right)$, and syringol $\left(\mathrm{C}_{8} \mathrm{H}_{10} \mathrm{O}_{3}\right)$ - can form secondary organic aerosol (SOA) at high yields. Here we examine the chemical characteristics of this SOA and its formation mechanisms using a High-Resolution Time-of-Flight Aerosol Mass Spectrometer (HR-AMS), an Ion Chromatography system (IC), and a Total Organic Carbon (TOC) analyzer. The phenolic SOA are highly oxygenated with oxygen-to-carbon $(\mathrm{O} / \mathrm{C})$ ratios in the range of $0.80-1.06$ and carbon oxidation states $(=2 \times \mathrm{O} / \mathrm{C}-\mathrm{H} / \mathrm{C})$ between -0.14 and +0.47 . The organic mass-to-carbon $(\mathrm{OM} / \mathrm{OC})$ ratios determined by the HR-AMS $(=2.21-2.55)$ agree well with values determined based on the SOA mass measured gravimetrically and the OC mass from the TOC analyzer. Both the $\mathrm{O} / \mathrm{C}$ and $\mathrm{OM} / \mathrm{OC}$ ratios of the phenolic SOA are similar to the values observed for ambient low-volatility oxygenated/secondary OA (LV-OOA). Oxalate is a minor, but ubiquitous, component of the SOA formed from all three phenolic precursors, accounting for $1.4-5.2 \%$ of the SOA mass, with generally higher yields in experiments with $\mathrm{H}_{2} \mathrm{O}_{2}$ added as an $\mathrm{OH}$ source compared to without. The AMS spectra show evidence for the formation of syringol and guaiacol dimers and higher oligomers via $\mathrm{C}-\mathrm{C}$ and $\mathrm{C}-\mathrm{O}$ coupling of phenoxyl radicals, which are formed through oxidation pathways such as abstraction of the phenolic hydrogen atom or $\mathrm{OH}$ addition to the aromatic ring. This latter pathway leads to hydroxylation of the aromatic ring, which is one mecha-
\end{abstract}

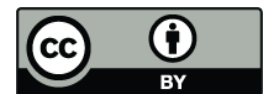

Correspondence to: $\mathrm{Q}$. Zhang

(dkwzhang@ucdavis.edu) nism that increases the degree of oxidation of the SOA products. Compared to direct photochemical reactions of the phenols, OH-initiated reactions favor the formation of smaller oxidation products but less dimers or higher oligomers. Two unique and prominent ions in the syringol and guaiacol SOA spectra, $m / z 306\left(\mathrm{C}_{16} \mathrm{H}_{18} \mathrm{O}_{6}^{+}\right)$and $m / z 246\left(\mathrm{C}_{14} \mathrm{H}_{14} \mathrm{O}_{4}^{+}\right)$, respectively, are observed in ambient aerosols significantly influenced by wood combustion and fog processing. Our results indicate that cloud and fog processing of phenolic compounds, especially in areas with active biomass burning, might represent an important pathway for the formation of low-volatility and highly oxygenated organic species, which would remain in the particle phase after fog/cloud evaporation and affect the chemical and optical properties of atmospheric particles.

\section{Introduction}

Organic aerosols (OA) account for a significant fraction of fine particulate mass in the atmosphere (Saxena and Hildemann, 1996; Kanakidou et al., 2005; Zhang et al., 2007) and likely play important roles in affecting the radiative balance of the Earth and air quality. However, there are large uncertainties in evaluating the impacts of OA on atmospheric chemistry, climate, and human health, due to many unknowns regarding their sources, composition, properties, and transformation mechanisms (Kanakidou et al., 2005; de Gouw and Jimenez, 2009; Hallquist et al., 2009).

Field studies indicate that a substantial fraction of atmospheric OA is secondary (SOA) (e.g., Zhang et al., 2007). While SOA is generally considered as a product from

Published by Copernicus Publications on behalf of the European Geosciences Union. 
Table 1. Summary of the SOA products of phenolic precursors obtained from aqueous photochemical reactions under different experimental conditions.

\begin{tabular}{|c|c|c|c|c|c|c|c|c|c|c|c|c|c|}
\hline \multirow[t]{2}{*}{$\begin{array}{l}\text { Sample } \\
\text { ID }\end{array}$} & \multirow[t]{2}{*}{$\begin{array}{l}\text { Precursor Compound (Formula, MW, } \\
\text { OM/OC, Carbon Oxidation State }{ }^{\mathrm{a}} \text { ) }\end{array}$} & \multicolumn{2}{|c|}{$\begin{array}{c}\text { Solution } \\
\text { Conditions }^{\mathrm{b}}\end{array}$} & \multirow{2}{*}{$\begin{array}{l}\text { SOA } \\
\text { mass }^{c} \\
(\mu \mathrm{g})\end{array}$} & \multirow[t]{2}{*}{$\begin{array}{l}\mathrm{SOC} \\
(\mu \mathrm{gC})\end{array}$} & \multicolumn{2}{|c|}{$\begin{array}{c}\text { Organic acids } \\
\text { (\% of SOA mass) }\end{array}$} & \multicolumn{6}{|c|}{ HR-AMS Measurements of Phenolic SOA } \\
\hline & & $\mathrm{H}_{2} \mathrm{O}_{2}$ & $\mathrm{pH}$ & & & Formate & Oxalate & $\mathrm{OM} / \mathrm{OC}$ & $\mathrm{O} / \mathrm{C}$ & $\mathrm{H} / \mathrm{C}$ & $\begin{array}{l}\text { SOA mass } \\
(\mu \mathrm{g})\end{array}$ & $\Sigma m / z_{>100}^{\mathrm{e}}$ & $\begin{array}{l}\text { Carbon Oxidation } \\
\text { State }^{\mathrm{a}}\end{array}$ \\
\hline A & $\begin{array}{l}\text { Phenol } \\
\left(\mathrm{C}_{6} \mathrm{H}_{6} \mathrm{O}, 94,1.31,-0.67\right)\end{array}$ & $\checkmark$ & 5 & 62.9 & 23.1 & $0.31 \%$ & $2.6 \%$ & 2.55 & 1.06 & 1.65 & 58.9 & $2.5 \%$ & +0.47 \\
\hline B & Guaiacol & $\checkmark$ & 5 & 83.6 & 32.4 & $0.24 \%$ & $3.6 \%$ & 2.37 & 0.92 & 1.69 & 76.8 & $6.7 \%$ & +0.15 \\
\hline $\mathrm{C}$ & $\left(\mathrm{C}_{7} \mathrm{H}_{8} \mathrm{O}_{2}, 124,1.48,-0.57\right)$ & & 5 & 40.6 & 20.8 & $0.29 \%$ & $1.9 \%$ & 2.25 & 0.83 & 1.70 & 46.8 & $6.7 \%$ & -0.04 \\
\hline $\mathrm{D}$ & Syringol & $\checkmark$ & 5 & 155 & 73.9 & $0.25 \%$ & $5.2 \%$ & 2.39 & 0.93 & 1.74 & 176 & $6.8 \%$ & +0.12 \\
\hline $\mathrm{E}$ & $\left(\mathrm{C}_{8} \mathrm{H}_{10} \mathrm{O}_{3}, 154,1.61,-0.50\right)$ & $\checkmark$ & 7 & 191 & 91.1 & $0.06 \%$ & $1.4 \%$ & 2.21 & 0.80 & 1.74 & 201 & $8.1 \%$ & -0.14 \\
\hline $\mathrm{F}$ & & & 5 & 168 & 83.2 & $0.10 \%$ & $1.4 \%$ & 2.21 & 0.80 & 1.67 & 184 & $6.9 \%$ & -0.07 \\
\hline
\end{tabular}

${ }^{a}$ Average degree of oxidation of the $\mathrm{C}$ atom $(=2 \times \mathrm{O} / \mathrm{C}-\mathrm{H} / \mathrm{C})$. More positive values indicate a greater degree of oxidation. ${ }^{\mathrm{b}}$ Indicates whether the illumination solution contained $\mathrm{H}_{2} \mathrm{O}_{2}(100 \mu \mathrm{M})$ as a photochemical source of $\mathrm{OH}$ and lists the initial $\mathrm{pH}$ of the solution, adjusted with $\mathrm{H}_{2} \mathrm{SO}_{4}$ or $\mathrm{NaHBO}_{4}$. All solutions were illuminated with simulated sunlight. There is no row for phenol $\left(\mathrm{C}_{6} \mathrm{H}_{6} \mathrm{O}\right)$ in the absence of $\mathrm{H}_{2} \mathrm{O}_{2}$ (i.e., light only) since no SOA was formed under this condition. ${ }^{\mathrm{c}}$ SOA mass measured gravimetrically. ${ }^{\mathrm{d}} \mathrm{SOA}$ mass reconstructed $(=\mathrm{SOC} \times \mathrm{OM} / \mathrm{OC})$. ${ }^{\mathrm{C}} \%$ of total ion signal at $m / z>100$ in the corresponding AMS spectrum.

gas-phase oxidation of volatile organic compounds (VOCs) and subsequent gas-to-particle partitioning, recent studies have shown that reactions in atmospheric aqueous phases may represent an important pathway for SOA production (Blando and Turpin, 2000; Kanakidou et al., 2005; Kroll and Seinfeld, 2008; Hallquist et al., 2009). For instance, formation of low-volatility high-molecular weight (MW) products has been observed during the aqueous-phase reactions of a number of organic compounds detected in atmosphere, including glycolaldehyde (Perri et al., 2009), glyoxal (Buxton et al., 1997; Carlton et al., 2007; Tan et al., 2009), methyglyoxal (Altieri et al., 2008), pyruvic acid (Altieri et al., 2006; Carlton et al., 2006; Guzmán et al., 2006), and methacrolein (Liu et al., 2009).

Recent work has shown substantial formation of lowvolatility materials in water solutions of phenols and methoxyphenols exposed to atmospherically relevant photochemical conditions (Anastasio and Sun, 2010). In addition, aqueous phenol reactions are also a source of light-absorbing molecules, i.e., humic-like substances (HULIS) (Gelencsér et al., 2003; Chang and Thompson, 2010). Phenols are common in ambient air and are especially abundant in areas of wood burning (Leuenberger et al., 1985; Sagebiel and Seiber, 1993; Lüttke et al., 1997) due to pyrolysis of lignin - a major component of wood tissue (Hawthorne et al., 1992; Simoneit, 1999). Oxidation of aromatic compounds and the entrainment of terrestrial humic/fulvic substances can also contribute phenols to the atmosphere (Graber and Rudich, 2006). While the study by Anastasio and Sun (2010) clearly indicates that in-cloud processing of phenols can be a source of SOA, little is known about the products. Characterizing the chemical composition of SOA is important to understanding the reaction mechanisms and representing them in models.

In this work we describe the chemical characteristics of the low-volatility, aqueous-phase reaction products of phenol $\left(\mathrm{C}_{6} \mathrm{H}_{6} \mathrm{O}, \mathrm{MW}=94\right)$, 2-methoxyphenol (guaiacol, $\mathrm{C}_{7} \mathrm{H}_{8} \mathrm{O}_{2}$,
$\mathrm{MW}=124$ ), and 2,6-dimethoxyphenol (syringol, $\mathrm{C}_{8} \mathrm{H}_{10} \mathrm{O}_{3}$, $\mathrm{MW}=154$ ), which represent the three basic structures of phenols emitted from wood combustion (Simoneit et al., 1993). The reactions were initiated in water solutions exposed to simulated sunlight illumination in the presence and absence of $\mathrm{H}_{2} \mathrm{O}_{2}$ as an $\mathrm{OH}$ source (Anastasio and Sun, 2010). Here we characterize the composition of the phenolic SOA, and elucidate the mechanisms responsible for its formation, based on analysis with an Aerodyne High-Resolution Timeof-Flight Aerosol Mass Spectrometer (HR-AMS) in conjunction with measurements of total organic carbon (TOC) and small organic acids.

\section{Experimental}

\subsection{Phenolic SOA preparation}

The SOA products of three phenolic model compounds phenol, guaiacol, and syringol - were prepared under two conditions: (1) simulated sunlight and (2) simulated sunlight with hydroxyl radical $(\mathrm{OH})$. Details of the experiments are given in Anastasio and Sun (2010) and are described here only briefly. The initial solutions were composed of airsaturated Milli-Q water containing $100 \mu \mathrm{M}$ of a single phenol and sulfuric acid or sodium borate to adjust the $\mathrm{pH}$; in experiments with $\mathrm{OH}$ we also added $100 \mu \mathrm{M} \mathrm{H}_{2} \mathrm{O}_{2}$ (Table 1). We used $100 \mu \mathrm{M}$ of initial phenol in order to be able to readily measure the SOA products. While this concentration is much higher than typical ambient levels of individual phenols (approximately $0.1-1 \mu \mathrm{M}$; Anastasio et al., 1997 and references therein), it is not much higher than the upper range of total concentrations of methoxyphenols observed in winter fog drops in northern California, where measured values range up to approximately $30 \mu \mathrm{M}$ (Sagebiel and Seiber, 1993). 
Solutions were illuminated in air-tight quartz cells at $20^{\circ} \mathrm{C}$ with simulated sunlight from a filtered $1000 \mathrm{~W}$ Xe lamp until approximately half of the initial phenol was degraded (as monitored by HPLC/UV-vis). At that point, $12.0 \mathrm{~mL}$ of the illuminated solution was placed in an aluminum ( $\mathrm{Al}$ ) cup and blown gently to dryness with $\mathrm{N}_{2}$ at room temperature. HPLC analysis of the blown-down material shows there are negligible amounts of the initial phenols remaining. Dark control experiments, carried out under same conditions except in the dark, showed negligible loss of phenol and negligible formation of SOA.

\subsection{High-resolution aerosol mass spectrometric analysis}

An HR-AMS (Aerodyne Res. Inc.; DeCarlo et al., 2006) was used to characterize the bulk composition of the phenolic SOA products. The Aerosol Mass Spectrometers (AMS) have been applied widely in lab experiments and field campaigns for quantitative characterization of aerosol composition (Canagaratna et al., 2007). They are able to quantify the total mass of organic substances in particles and provide an ensemble mass spectrum that bears information of their average composition (Zhang et al., 2005a; Canagaratna et al., 2007). The HR-AMS is an exceptionally useful instrument for chemical resolution of particle components since it is able to distinguish ions having the same nominal mass-to-charge ratio $(\mathrm{m} / \mathrm{z})$ but different elemental compositions (DeCarlo et al., 2006; Aiken et al., 2007, 2008).

Detailed procedures for liquid sample analysis with an AMS can be found in Sun and Zhang (2010). Briefly, the blown-down material in each Al cup was dissolved in $10.0 \mathrm{~mL}$ distilled-deionized water (DDWater, resistance $>18 \mathrm{M} \Omega-\mathrm{cm})$ and then aerosolized using a constant output atomizer (TSI, Model 3076). The resulting aerosols were dried by a diffusion dryer and then sampled into the HRAMS. Mass spectra were acquired with the HR-AMS operated under the settings typically used for ambient studies, e.g., at heater temperature of $600{ }^{\circ} \mathrm{C}$ and electron ionizing voltage of $70 \mathrm{eV}$. The HR-AMS alternated between two ion optical modes that are referred to as "V" and "W" according to the ion paths (DeCarlo et al., 2006). The $m / z$ resolution of $\mathrm{V}$-mode $(\sim 3000)$ is lower than that of $\mathrm{W}$-mode $(\sim 6000)$, but the sensitivity of V-mode is almost 100 times higher (DeCarlo et al., 2006; Sun et al., 2009). Between every two sample runs, DDwater was aerosolized and analyzed as an analytical blank. In order to better distinguish oligomer signals in the spectra, the SOA products of syringol were also analyzed at a lower AMS vaporizer temperature of $200^{\circ} \mathrm{C}$.

\subsection{Analysis of high resolution mass spectra (HRMS)}

All data analysis was performed with Igor Pro 6.05 (Wavemetrics, Lake Oswego, OR). The V- and W-mode spectra of each sample were analyzed with the AMS data analysis software (SQUIRREL v1.46 and PIKA v.1.05) downloaded from http://cires.colorado.edu/jimenez-group/ ToFAMSResources/ToFSoftware. Note that PIKA analysis is usually limited to ions $<100 \mathrm{amu}$ for ambient aerosols due to the general trend of increasing number of possible isobaric ions with $m / z$ value. It thus requires higher resolution to unambiguously separate adjacent ions at larger $m / z$ 's. However, because the phenolic SOA products studied here should consist of only $\mathrm{C}, \mathrm{H}$, and $\mathrm{O}$ and the number of ions at each integer $m / z$ is much reduced compared to ambient OA, PIKA analysis was performed to all peaks with good signalto-noise (S/N), including $m / z$ 's $>100$.

Elemental analysis was performed to the $\mathrm{W}$-mode data to determine the average $\mathrm{O} / \mathrm{C}$ and $\mathrm{H} / \mathrm{C}$ ratios of the SOA products (Aiken et al., 2007; Aiken et al., 2008). Because our experimental setup appears to dry aerosols effectively, according to tests on water signals in the AMS mass spectra of aerosol generated from highly soluble salts (e.g., $\mathrm{NH}_{4} \mathrm{Cl}$ and $\mathrm{CH}_{3} \mathrm{NH}_{2} \cdot \mathrm{HCl}$ ) (Sun et al., 2010), we assume no contributions from physically-bonded particulate or gaseous water in the raw mass spectra. The $\mathrm{H}_{2} \mathrm{O}^{+}$signal of organics was thus determined as the difference between the measured $\mathrm{H}_{2} \mathrm{O}^{+}$ signal and that produced by sulfates (Allan et al., 2004). The $\mathrm{H}_{2} \mathrm{O}^{+}$signal of organics showed a good correlation with the measured $\mathrm{CO}_{2}^{+}$signal $\left(r^{2}=0.97\right.$; slope $\left.=0.8\right)$. We therefore set $\mathrm{H}_{2} \mathrm{O}^{+}=0.8 \mathrm{CO}_{2}^{+}$for the HRMS analysis and set $\mathrm{OH}^{+}=$ $25 \% \mathrm{H}_{2} \mathrm{O}^{+}$and $\mathrm{O}^{+}=4 \% \mathrm{H}_{2} \mathrm{O}^{+}$based on the fragmentation pattern of water molecule (Allan et al., 2004).

The $\mathrm{CO}^{+}$signal in the HRMS was also scaled to the $\mathrm{CO}_{2}^{+}$ signal since the large $\mathrm{N}_{2}^{+}$signal (from $\mathrm{N}_{2}$ in the air) may interfere with the quantification of the adjacent $\mathrm{CO}^{+}$peak (Aiken et al., 2008; Sun et al., 2009). The average ratio of $\mathrm{CO}^{+} / \mathrm{CO}_{2}^{+}$was determined at $\sim 0.8$ based on the syringol SOA spectra (Fig. S1 http://www.atmos-chem-phys.net/10/ 4809/2010/acp-10-4809-2010-supplement.pdf), which show relatively well separated $\mathrm{CO}^{+}$and $\mathrm{N}_{2}^{+}$peaks with good $\mathrm{S} / \mathrm{N}$, and thus, $\mathrm{CO}^{+}$is set equal to $0.8 \times \mathrm{CO}_{2}^{+}$in this study.

\subsection{Ion Chromatography (IC) and Total Organic Carbon (TOC) analysis}

Organic and inorganic anions (e.g., formate, acetate, oxalate, and $\mathrm{SO}_{4}^{2-}$ ) were analyzed with an anion IC system (Metrohm AG, Switzerland) equipped with a Metrosep A Supp 5-250 column. TOC concentrations were quantified with a Sievers 900 TOC Analyzer (GE Analytical Instruments). Recoveries of known additions in samples are generally within $95-110 \%$. Relative standard errors for replicate analyses are always within $3 \%$ and were usually less than $2 \%$. 


\section{Results and discussion}

\subsection{Background information on SOA yields and phenol reaction kinetics}

Aqueous photoreactions of all three of the phenols form lowvolatility products (i.e., SOA) with mass yields near unity (Anastasio and Sun, 2010). The actual mass yields of SOA under ambient atmospheric conditions are likely higher because semi-volatile species probably more extensively evaporate during our drying procedure (see Sect. 2.1) than in ambient particles. However, based on the SOA carbon yields, we estimate that volatile and semi-volatile materials (e.g., $\mathrm{CO}, \mathrm{CO}_{2}$, and small organic compounds) lost during reaction and/or drying accounted for only $\sim 20 \%$ of the reacted phenol mass. Since almost no original phenolic compounds were detected in the solids left in the $\mathrm{Al}$ cup after drying, we are confident that the organic materials analyzed for this study are indeed the low-volatility SOA products. Finally, using this blow-down procedure shows that the phenolic SOA is stable both in solution as well as under dry conditions.

As described in Anastasio and Sun (2010), the lifetimes of phenols in atmospheric fog and cloud water drops with respect to $\mathrm{OH}$ reaction are on the order of a few hours during daytime; similarly, the illumination times required to produce the SOA products studied here in the presence of $\mathrm{OH}$ were approximately an hour (syringol), a few hours (guaia$\mathrm{col}$ ), and $20 \mathrm{~h}$ (phenol). While all three compounds have similar reaction rate constants with OH (NDRL, 2002), the exposure times for the three phenols vary because of large differences in the rates of direct photoreactions: while phenol has no direct photoreaction, this pathway is relatively rapid for syringol, and is intermediate for guaiacol (Anastasio and Sun, 2010). Because the lifetimes of gas-phase phenols with respect to $\mathrm{OH}$ reaction are of the same order as the aqueous phenols (i.e., hours) (Feigenbrugel et al., 2004), the relative importance of the aqueous- and gas-phase reaction pathways depends strongly on the gas-aqueous partitioning of the phenols. Based on Henry's law constants for the phenols (Sagebiel et al., 1992; Sagebiel and Seiber, 1993; Guo and Brimblecombe, 2007), under typical cold cloud conditions $\left(5^{\circ} \mathrm{C}\right.$, $0.3 \mathrm{~g}-\mathrm{H}_{2} \mathrm{O} \mathrm{m}^{-3}$ ), approximately $3 \%$ (guaiacol), $4 \%$ (phenol), and $15 \%$ (syringol) of these phenols will be in the aqueous phase; however, field measurements have shown that aqueous concentrations of methoxyphenols are often a factor of three or four higher than predicted from Henry's law (Sagebiel and Seiber, 1993).

\subsection{Bulk chemical characteristics and elemental composition of phenolic SOA}

Figure 1 shows the HRMS of SOA products, in which each peak is apportioned according to the contributions of six ion categories $-\mathrm{C}_{\mathrm{x}} \mathrm{H}_{\mathrm{y}}^{+}, \mathrm{H}_{\mathrm{y}} \mathrm{O}_{1}^{+}, \mathrm{C}_{\mathrm{x}} \mathrm{H}_{\mathrm{y}} \mathrm{O}_{1}^{+}, \mathrm{C}_{\mathrm{x}} \mathrm{H}_{\mathrm{y}} \mathrm{O}_{2}^{+}, \mathrm{C}_{\mathrm{x}} \mathrm{H}_{\mathrm{y}} \mathrm{O}_{3}^{+}$, and $\mathrm{C}_{\mathrm{x}} \mathrm{H}_{\mathrm{y}} \mathrm{O}_{4}^{+}(\mathrm{x} \geq 1 ; \mathrm{y} \geq 0)$. The mass spectra for all SOA products are dominated by $\mathrm{C}_{\mathrm{x}} \mathrm{H}_{\mathrm{y}}^{+}, \mathrm{C}_{\mathrm{x}} \mathrm{H}_{\mathrm{y}} \mathrm{O}_{1}^{+}$, and $\mathrm{C}_{\mathrm{x}} \mathrm{H}_{\mathrm{y}} \mathrm{O}_{2}^{+}$, which together account for more than $80 \%$ of the total signal (Fig. 1). All SOA spectra show largest peaks at $m / z 44\left(\mathrm{CO}_{2}^{+}\right.$ ), $18\left(\mathrm{H}_{2} \mathrm{O}^{+}\right)$, and $28\left(\mathrm{CO}^{+}\right)$and an overall pattern similar to that of fulvic acid, which has been suggested as a model representation for highly processed and oxidized OA (OOA) and HULIS (Alfarra, 2004; Zhang et al., 2005a). The O/C ratios of these SOA are in the range of 0.80-1.06 (Table 1), which are close to the values observed for ambient lowvolatility, regional OOA/SOA (LV-OOA, or OOA-1) (Aiken et al., 2008; Jimenez et al., 2009). Thus the aqueous-phase photooxidation of phenolic compounds forms SOA species similarly oxidized as ambient SOA.

The oxidation state of carbon (OSC) in an organic compound containing only $\mathrm{C}, \mathrm{H}$, and $\mathrm{O}$ atoms can be determined as $2 \times \mathrm{O} / \mathrm{C}-\mathrm{H} / \mathrm{C}$ based on the assumption that oxygen has an oxidation state of -2 and hydrogen of +1 (Kroll et al., 2009). Higher OSC indicates more oxidized molecule, e.g., the OSC of $\mathrm{CO}_{2}=+4$ and that of $\mathrm{CH}_{4}=-4$. The average OSC of phenolic SOA range between -0.14 and +0.47 , significantly higher than the values of their precursor compounds (i.e., $-0.67--0.50$; Table 1 ). In addition, the SOA of phenol $\left(\mathrm{C}_{6} \mathrm{H}_{6} \mathrm{O}\right)$ is overall the most oxidized while the SOA of guaiacol and syringol are of a similar degree of oxidation. Compared to illumination only, the presence of $\mathrm{H}_{2} \mathrm{O}_{2}$ (as a source of $\mathrm{OH}$ ) produced more oxidized SOA (Fig. 1); this is probably due to enhanced hydroxylation of the aromatic ring as well as to increased yields of carboxylic acids (e.g., oxalate) in $\mathrm{OH}$-initiated reactions (see next sections).

The OM/OC ratios determined based on the HRMS are in the range of 2.21-2.55 (Table 1), which are close to the values estimated for ambient OOA/SOA (Zhang et al., 2005b; Aiken et al., 2008) and nonurban OA (2.1 \pm 0.2$)$ (Turpin and Lim, 2001). Note that the OM/OC ratios determined by the HR-AMS agree well with those determined based on the SOA mass measured gravimetrically (Anastasio and Sun, 2010) and the OC mass from the TOC analyzer. A linear regression between the SOA masses reconstructed from HRAMS $(=\mathrm{OM} / \mathrm{OC} \times \mathrm{TOC})$ and those measured gravimetrically yields $r^{2}=0.99$ and slope $=1.07$ (Fig. 2).

For guaiacol and syringol, the mass spectral patterns and ion compositions of SOA formed from the same precursor are similar on a big scale for both light only and light plus $\mathrm{OH}$ conditions. But there are important differences in the degree of oxidation as the SOA produced under light plus $\mathrm{OH}$ conditions are more oxidized than those produced under light only (Table 1). No SOA was formed from an illuminated phenol $\left(\mathrm{C}_{6} \mathrm{H}_{6} \mathrm{O}\right)$ solution in the absence of $\mathrm{H}_{2} \mathrm{O}_{2}$ (i.e., light only).

The mass spectral patterns from different precursors are more different, particularly at high $\mathrm{m} / z$ 's (Figs. 1 and S2 http://www.atmos-chem-phys.net/10/4809/ 2010/acp-10-4809-2010-supplement.pdf). This trend can be viewed clearly in Fig. 3, which shows the distributions of ion signal, $\mathrm{H} / \mathrm{C}$, and $\mathrm{O} / \mathrm{C}$ as a function of carbon number in the 


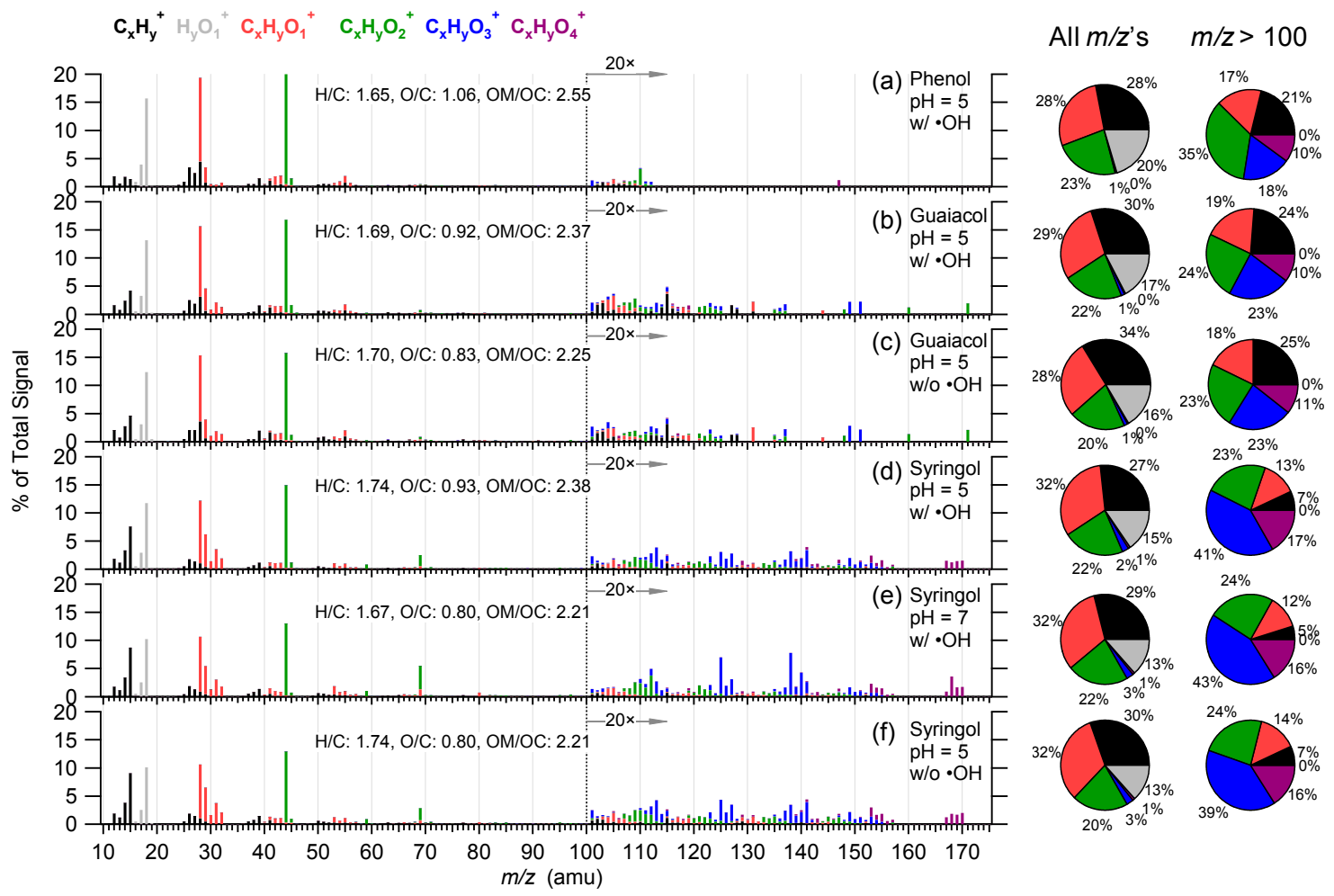

Fig. 1. HRMS of the SOA products of (a) phenol, (b-c) guaiacol, and (d-f) syringol formed via aqueous-phase photochemical reactions. Each peak in the HRMS is colored based on the contributions from 6 ion categories: $\mathrm{C}_{\mathrm{x}} \mathrm{H}_{\mathrm{y}}^{+}, \mathrm{H}_{\mathrm{y}} \mathrm{O}_{1}^{+}, \mathrm{C}_{\mathrm{x}} \mathrm{H}_{\mathrm{y}} \mathrm{O}_{1}^{+}, \mathrm{C}_{\mathrm{x}} \mathrm{H}_{\mathrm{y}} \mathrm{O}_{2}^{+}, \mathrm{C}_{\mathrm{x}} \mathrm{H}_{\mathrm{y}} \mathrm{O}_{3}^{+}$, and $\mathrm{C}_{\mathrm{x}} \mathrm{H}_{\mathrm{y}} \mathrm{O}_{4}^{+}$. The ion signals at $m / z>100$ are enhanced by a factor of 20 for clarity. The pie charts show the relative contributions of each ion category to individual SOA material. The experimental conditions and the calculated atomic ratios are shown in the legends.

SOA spectra. In all SOA spectra, the majority of the total signal is associated with ions containing $<2 \mathrm{C}$ atoms (Fig. 3). The high $\mathrm{O} / \mathrm{C}$ ratio in $\mathrm{C}_{1}$ ions is due to the dominant contributions from $\mathrm{CO}^{+}$and $\mathrm{CO}_{2}^{+}$. Relatively unique fragment ions are observed for SOA formed from different precursors (Fig. 1), e.g., $\mathrm{C}_{6} \mathrm{H}_{6} \mathrm{O}_{2}^{+}(m / z=110)$ for phenol, $\mathrm{C}_{11} \mathrm{H}_{7} \mathrm{O}_{2}^{+}$ $(m / z=171)$ for guaiacol, and $\mathrm{C}_{6} \mathrm{H}_{5} \mathrm{O}_{3}^{+}(m / z=125)$ for syringol. In addition, while $\mathrm{m} / z 69$ stands out in the syringol SOA spectra, the two isobaric peaks $\left(\mathrm{C}_{3} \mathrm{HO}_{2}^{+}\right.$and $\left.\mathrm{C}_{4} \mathrm{H}_{5} \mathrm{O}^{+}\right)$ are also observed in the guaiacol SOA, but at much lower relative intensity. These results suggest that the SOA products from different phenolic compounds are likely significantly different despite the formation of some common compounds (e.g., organic acids; see Sect. 3.2). However, it is also possible that the differences observed in AMS fragmentation patterns are due to the different level of methoxy substitution on the precursors and therefore, in the products. Indeed, as discussed in Sect. 3.3., there are clear evidences that similar types of products, e.g., dimers and higher oligomers, are formed from both syringol and guaiacol.

Since electron impact produces ions no larger than the molecular ions, the detection of significant amounts of high $m / z$ fragments in the SOA spectra indicate the formation of higher molecular weight (MW) species, likely via oxygen incorporation and/or oligomerization. The high-MW SOA species seem to correlate with the precursor compounds in terms of molecular mass and $\mathrm{O} / \mathrm{C}$ ratios. For example, compared to guaiacol and phenol, the SOA products of syringol generate substantially more signal at $m / z>100$ (Table 1 and Fig. 4), of which a large fraction is associated with multiple-oxygenated ions, i.e., $\mathrm{C}_{\mathrm{x}} \mathrm{H}_{\mathrm{y}} \mathrm{O}_{2}^{+}, \mathrm{C}_{\mathrm{x}} \mathrm{H}_{\mathrm{y}} \mathrm{O}_{3}^{+}$, and $\mathrm{C}_{\mathrm{x}} \mathrm{H}_{\mathrm{y}} \mathrm{O}_{4}^{+}$(Fig. 1). Overall, the high $\mathrm{m} / \mathrm{z}$ fragments in the SOA spectra generally increase in signal intensity and $\mathrm{O} / \mathrm{C}$ ratios following the order of phenol, guaiacol, and syringol (Fig. 3). These results suggest that the high-MW species in phenolic SOA mirror the composition and molecular mass of their precursors. Syringol appears to form high-MW species most efficiently. In addition, the high-MW species formed from syringol appear to have highest $\mathrm{O} / \mathrm{C}$ ratios despite the fact that the SOA of phenol is overall more oxidized than those of guaiacol and syringol.

\section{Formation of organic acids}

The IC analysis shows the ubiquitous formation of small organic acids in the aqueous phenolic solutions during 


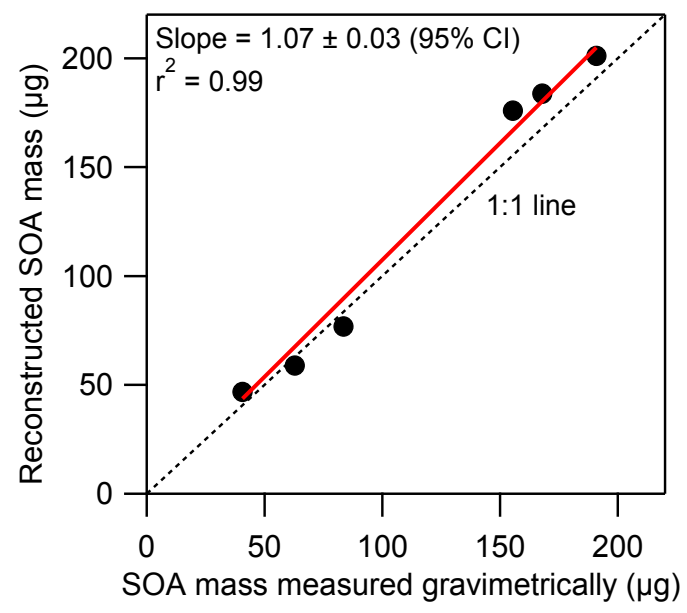

Fig. 2. Comparison of the reconstructed masses of phenolic SOA products $(=\mathrm{TOC} \times \mathrm{OM} / \mathrm{OC})$ versus their masses measured by gravimetric analysis. TOC was measured by a total carbon analyzer and OM/OC determined by the HR-AMS. The linear fit with the regression through zero was performed using an orthogonal distance regression (ODR) model.

exposure to simulated sunlight. Oxalate accounts for $1.4-5.2 \%$ of the SOA mass (Table 1); it appears that $\mathrm{OH}$ promotes the formation of oxalate. The concentrations of formate and acetate are very low in both the light and dark experiments, likely due to evaporative losses when the solutions were blown dry. Some unknown small peaks were also observed in the ion chromatograms (e.g., Fig. S3 (http://www.atmos-chem-phys.net/ 10/4809/2010/acp-10-4809-2010-supplement.pdf) for guaiacol SOA), indicating that unidentified organic acids contribute to the SOA products as well. However, injections of organic acid standards show that the unknown peaks are not glycolate, pyruvate, succinate, or benzoate. Previous studies have shown that glyoxylate is a direct precursor of oxalate formation in the aqueous phase (Ervens et al., 2004; Lim et al., 2005). Although this compound was not analyzed in this study, it could be one of the unidentified peaks judging from their retention times in the IC (Fig. S3 http://www.atmos-chem-phys.net/10/4809/2010/ acp-10-4809-2010-supplement.pdf).

The detection of small acids demonstrates that aqueous reactions of phenols can open the aromatic ring and form highly oxygenated aliphatic products, although the mechanism is not known. Ervens et al. (2003) suggested that incloud chemistry may facilitate the formation of oxalic acid from aromatic compounds. But in this mechanism the ring is cleaved in the gas phase, forming products which dissolve into the aqueous phase and then are oxidized to organic acids.
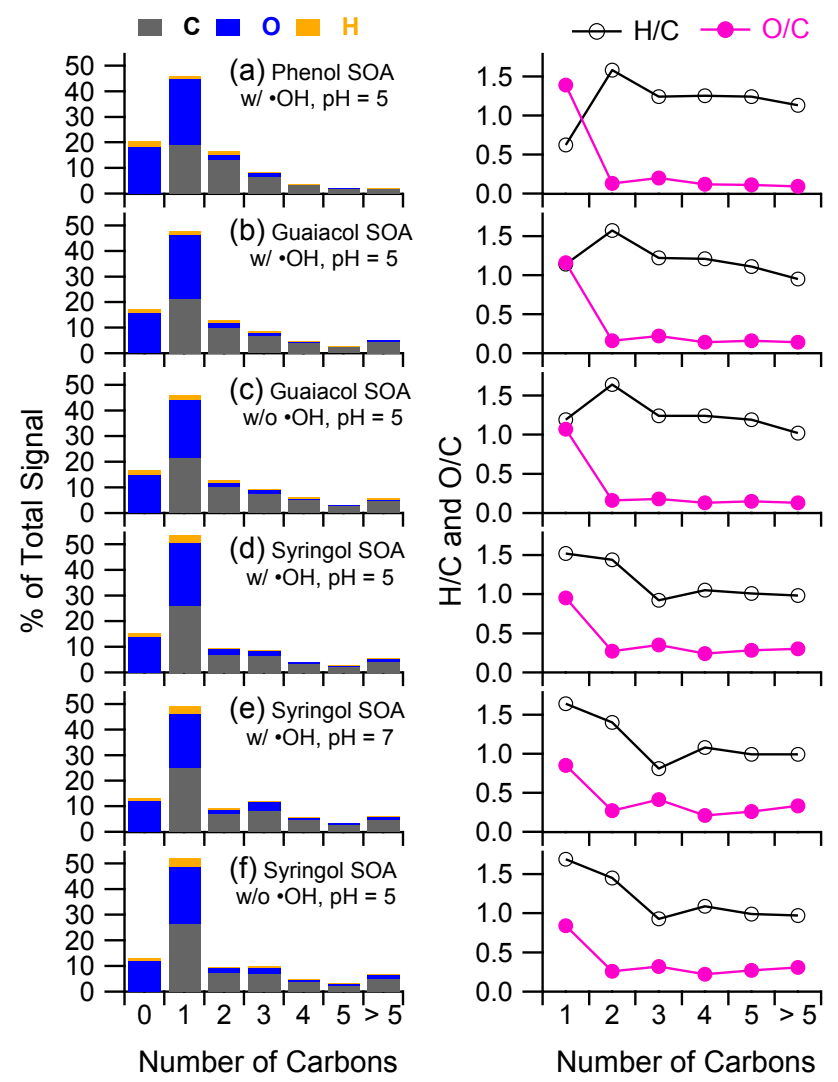

Fig. 3. Distribution of elements $(\mathrm{C}, \mathrm{O}$, and $\mathrm{H})$ and elemental ratios $(\mathrm{H} / \mathrm{C}$ and $\mathrm{O} / \mathrm{C})$ as a function of the number of carbons in each AMS fragment of the SOA products for (a) phenol, (b-c) guaiacol, (d-f) syringol. The experimental conditions are shown in the legends.

\subsection{Formation of phenolic dimers and higher oligomers}

Phenols are known to undergo radical recombination in the aqueous phase, forming dimers and higher oligomers (e.g., Kobayashi and Higashimura, 2003). The mechanism involves $\mathrm{C}-\mathrm{C}$ or $\mathrm{C}-\mathrm{O}$ coupling of phenoxy radicals, which are formed via oxidation pathways such as abstraction of the phenolic hydrogen atom or $\mathrm{OH}$ addition to the aromatic ring (Fig. 5). Oligomers have been detected in our SOA products of guaiacol (Fig. 6). $\mathrm{C}_{14} \mathrm{H}_{14} \mathrm{O}_{4}^{+}(m / z$ 246), which is the molecular ion $\left(\mathrm{M}^{+}\right)$and the base peak in the NIST spectrum of the guaiacol C-C dimer, is a major peak above $m / z 100$ in the AMS spectra of guaiacol SOA (Figs. 6a and 4b). Note that organic compounds with stable structures (e.g., PAHs; Dzepina et al., 2007) may form $\mathrm{M}^{+}$significantly in the AMS, despite high temperature vaporization $\left(\sim 600^{\circ} \mathrm{C}\right)$ that may lead to thermal decomposition and additional fragmentation in EI. The HR-AMS confirms that the peak at $m / z 246$ is almost purely $\mathrm{C}_{14} \mathrm{H}_{14} \mathrm{O}_{4}^{+}$and that the peak at $m / z 247$ is its $\mathrm{C}-13$ isotope ion $\left({ }^{13} \mathrm{CC}_{13} \mathrm{H}_{14} \mathrm{O}_{4}^{+}\right)$. The formation of guaiacol dimers during irradiation of aqueous solutions of guaiacol and $\mathrm{H}_{2} \mathrm{O}_{2}$ was also confirmed by Chang and Thomp- 


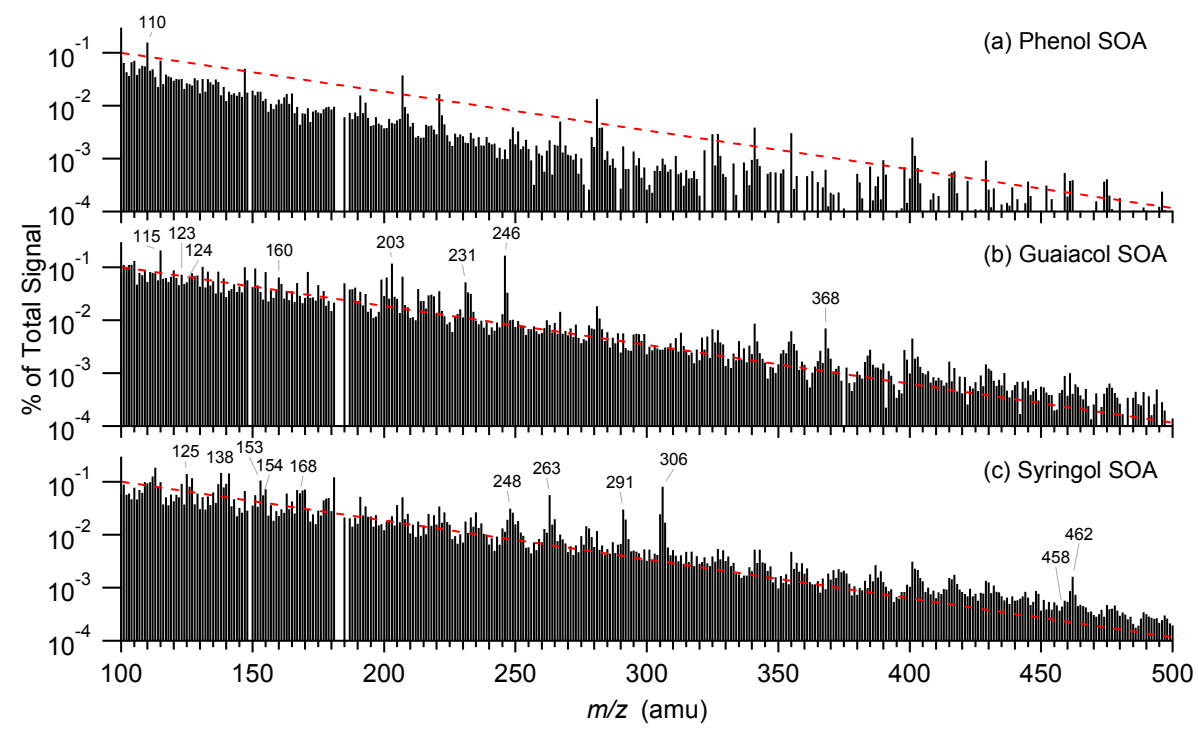

Fig. 4. The unit mass resolution (UMR) spectra $(m / z, 100-500)$ of phenolic SOA produced via aqueous-phase photoreactions in the presence of $\mathrm{OH}$ at $\mathrm{pH}=5$ : (a) phenol, (b) guaiacol, and (c) syringol. The red lines are shown to guide the eyes.

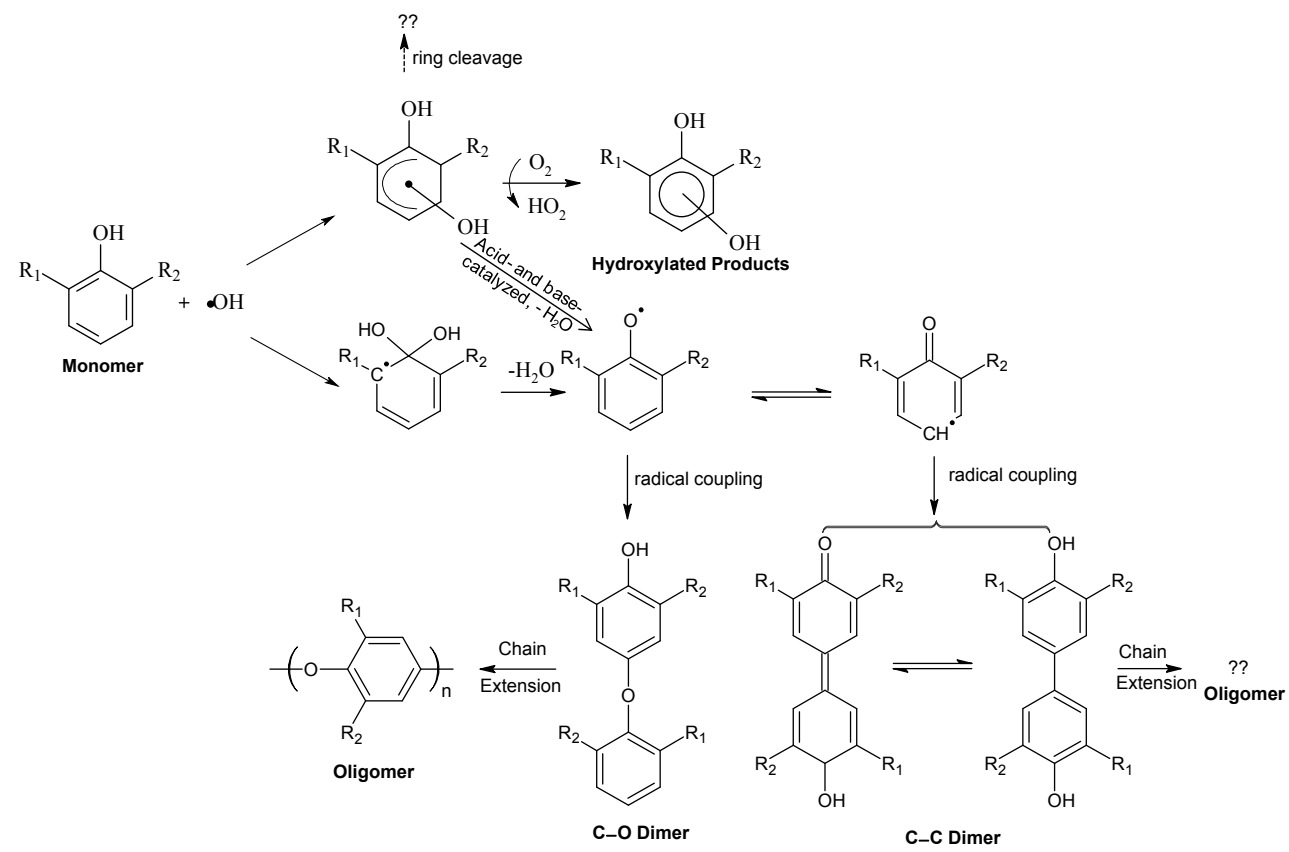

Fig. 5. Proposed mechanisms for formation of hydroxylated species (e.g., Olariu et al., 2002) and dimer and higher oligomers (e.g., Kobayashi and Higashimura, 2003) from phenolic precursors. Phenol: $R_{1}=H, R_{2}=H$; Guaiacol: $R_{1}=\mathrm{OCH}_{3}, R_{2}=H$; Syringol: $R_{1}=\mathrm{OCH}_{3}, R_{2}=\mathrm{OCH}_{3}$. Note that while radical coupling here (and in Fig. 7) is shown through the carbon opposite (para) the phenoxyl group, other geometric isomers will also be formed during these reactions.

son (2010) using Electrospray Ionization Mass Spectrometry (ESI-MS). However, it is important to note that the concentrations of phenolic precursors $(100 \mu \mathrm{M})$ used in our experiments are 100 times lower. Other major peaks such as $m / z 231,203,160,123$, and 115 in the NIST dimer spectrum are all significant peaks in the guaiacol SOA spectra (Fig. 6).
The C-O dimer of guaiacol, for which no NIST spectrum is available, is expected to give a similar fragmentation pattern since its structure is very similar to that of the $\mathrm{C}-\mathrm{C}$ dimer. Indeed, the NIST mass spectra of C-C and C-O dimers of phenol are almost identical, as described in Sect. 3.4. 


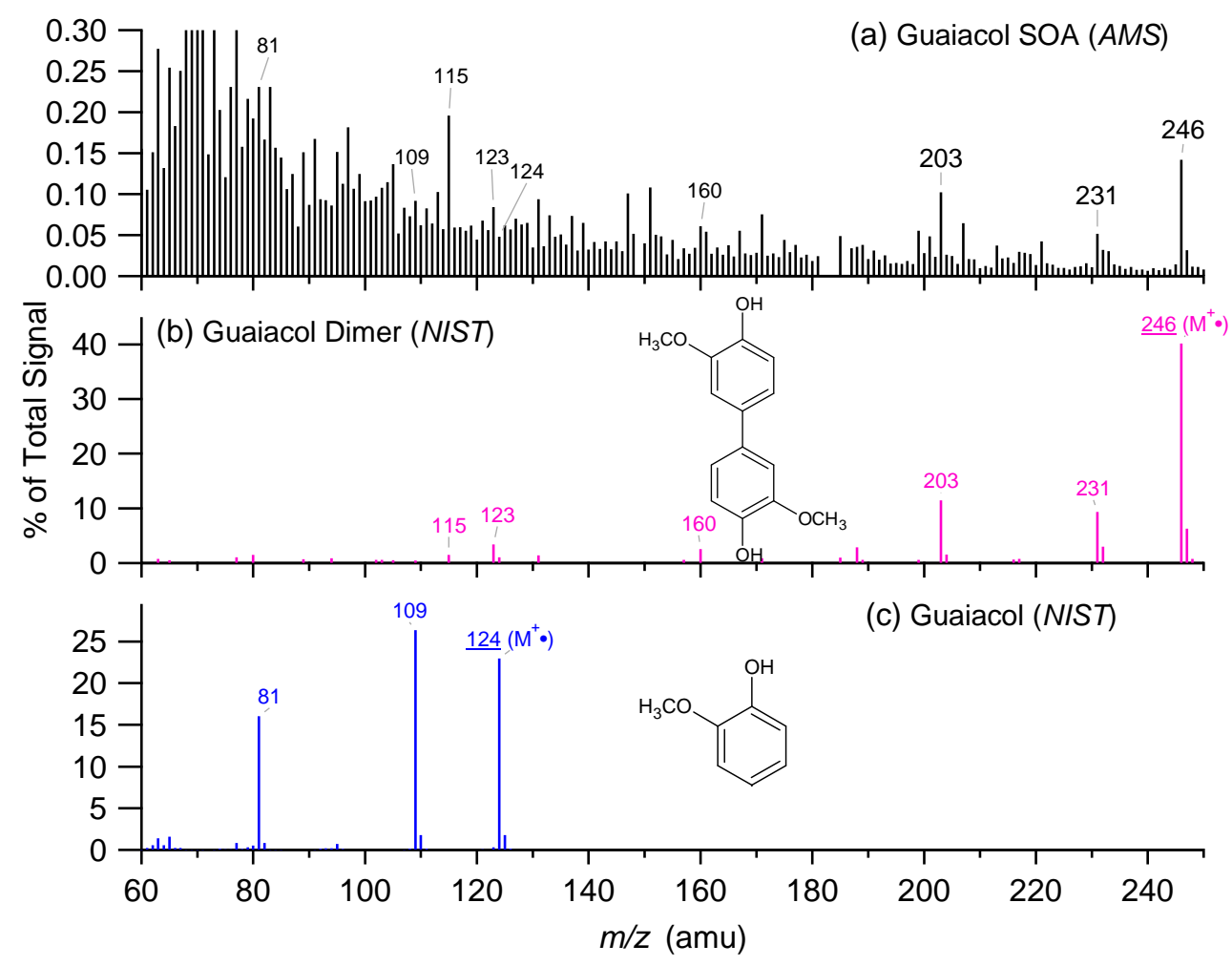

Fig. 6. Comparisons of (a) the AMS mass spectrum (in integer $m / z$ ) of guaiacol SOA formed via aqueous-phase photoreactions (w/ OH, $\mathrm{pH}=5$ ) with (b) the NIST mass spectrum of the C-C coupled dimer of guaiacol and (c) the NIST mass spectrum of guaiacol. The molecular ions $\left(\mathrm{M}^{+}\right)$are marked and the molecular structures of guaiacol and the guaiacol C-C dimer are shown.

Characteristic dimer peaks have also been identified in the mass spectra of syringol SOA, but no NIST spectra are available for syringol dimers. The $\mathrm{M}^{+}$of the syringol dimer $\left(\mathrm{C}_{16} \mathrm{H}_{18} \mathrm{O}_{6}^{+}, m / z\right.$ 306) sticks significantly above its neighbors and is the largest peak in the syringol SOA spectra above $200 \mathrm{amu}$ (Fig. 4). HR-AMS confirms $\mathrm{m} / z 306$ being primarily $\mathrm{C}_{16} \mathrm{H}_{18} \mathrm{O}_{6}^{+}$and $m / z 307$ being its isotope $\left({ }^{13} \mathrm{CC}_{15} \mathrm{H}_{18} \mathrm{O}_{6}^{+}\right)$. Other major peaks such as $\mathrm{m} / z 291$ $\left(\mathrm{C}_{15} \mathrm{H}_{15} \mathrm{O}_{6}^{+}\right), 263\left(\mathrm{C}_{14} \mathrm{H}_{15} \mathrm{O}_{5}^{+}\right)$, and $248\left(\mathrm{C}_{13} \mathrm{H}_{12} \mathrm{O}_{5}^{+}\right)$in the syringol SOA spectra (Fig. $7 \mathrm{~b}-\mathrm{d}$ ) are expected to form from logical neutral loss (e.g., $\mathrm{CH}_{3}, \mathrm{CO}$, and $\mathrm{H}_{2} \mathrm{O}$ etc.) from $\mathrm{M}^{+}$ (McLafferty and Turecek, 1993).

The postulated fragmentation pathways of syringol dimers (Fig. 7a) explain well the detection of main peaks at $\mathrm{m} / z$ 's $168\left(\mathrm{C}_{8} \mathrm{H}_{8} \mathrm{O}_{4}^{+}\right), 153\left(\mathrm{C}_{7} \mathrm{H}_{5} \mathrm{O}_{4}^{+}, \mathrm{C}_{8} \mathrm{H}_{9} \mathrm{O}_{3}^{+}\right), 138\left(\mathrm{C}_{7} \mathrm{H}_{6} \mathrm{O}_{3}^{+}\right)$, and $125\left(\mathrm{C}_{6} \mathrm{H}_{5} \mathrm{O}_{3}^{+}\right)$in the spectra of syringol SOA (Fig. $7 \mathrm{~b}-$ d). Furthermore, the compositions of the ions are confirmed by the HRMS. For example, the detection of isobaric ions $\left(\mathrm{C}_{7} \mathrm{H}_{5} \mathrm{O}_{4}^{+}\right.$and $\left.\mathrm{C}_{8} \mathrm{H}_{9} \mathrm{O}_{3}^{+}\right)$at $\mathrm{m} / z \quad 153$ (Fig. 7e) is consistent with the fragmentation mechanisms of $\mathrm{C}-\mathrm{C}$ and $\mathrm{C}-\mathrm{O}$ coupled dimers of syringol (Fig. 7a). Analysis of the mass spectra of guaiacol SOA also gives results consistent with guaiacol dimers (Fig. S4 http://www.atmos-chem-phys.net/10/4809/ 2010/acp-10-4809-2010-supplement.pdf).
In addition, we see evidence for the formation of higher molecular weight oligomers, e.g., the guaiacol trimer $\left(m / z \quad 368, \quad \mathrm{C}_{21} \mathrm{H}_{20} \mathrm{O}_{6}^{+}\right.$, Fig. 4b) and a series of syringol oligomers $(\Delta m / z=14$ and 18 , Fig. S5a http://www.atmos-chem-phys.net/10/4809/2010/ acp-10-4809-2010-supplement.pdf). Note that these signals are relatively low at an AMS vaporizer temperature of $600^{\circ} \mathrm{C}$, probably due to thermal decomposition on the vaporizer. The relative abundances of the high $\mathrm{m} / \mathrm{z}$ ions, including the trimer $\mathrm{M}^{+}$and its daughter ions, are significantly enhanced at lower vaporizer temperature $\left(200^{\circ} \mathrm{C}\right)$ (Fig. S5b http://www.atmos-chem-phys.net/10/4809/2010/ acp-10-4809-2010-supplement.pdf). All of these results confirm the formation of dimers and higher oligomers via coupling of phenoxy radicals during the aqueous-phase photoreactions of guaiacol and syringol.

\subsection{Formation of hydroxylated phenolic species}

In comparison to guaiacol and syringol, the evidence for dimer formation from phenol is less obvious in its SOA spectrum. The $\mathrm{M}^{+}$of phenol dimers, i.e., $\mathrm{C}_{12} \mathrm{H}_{10} \mathrm{O}_{2}^{+}(\mathrm{m} / z$ 186), is relatively low in the phenol SOA spectrum (Fig. 8a), although it is the base peak in the NIST spectrum of phenol dimers (Fig. 8d). Similarly, almost no dimer formation 

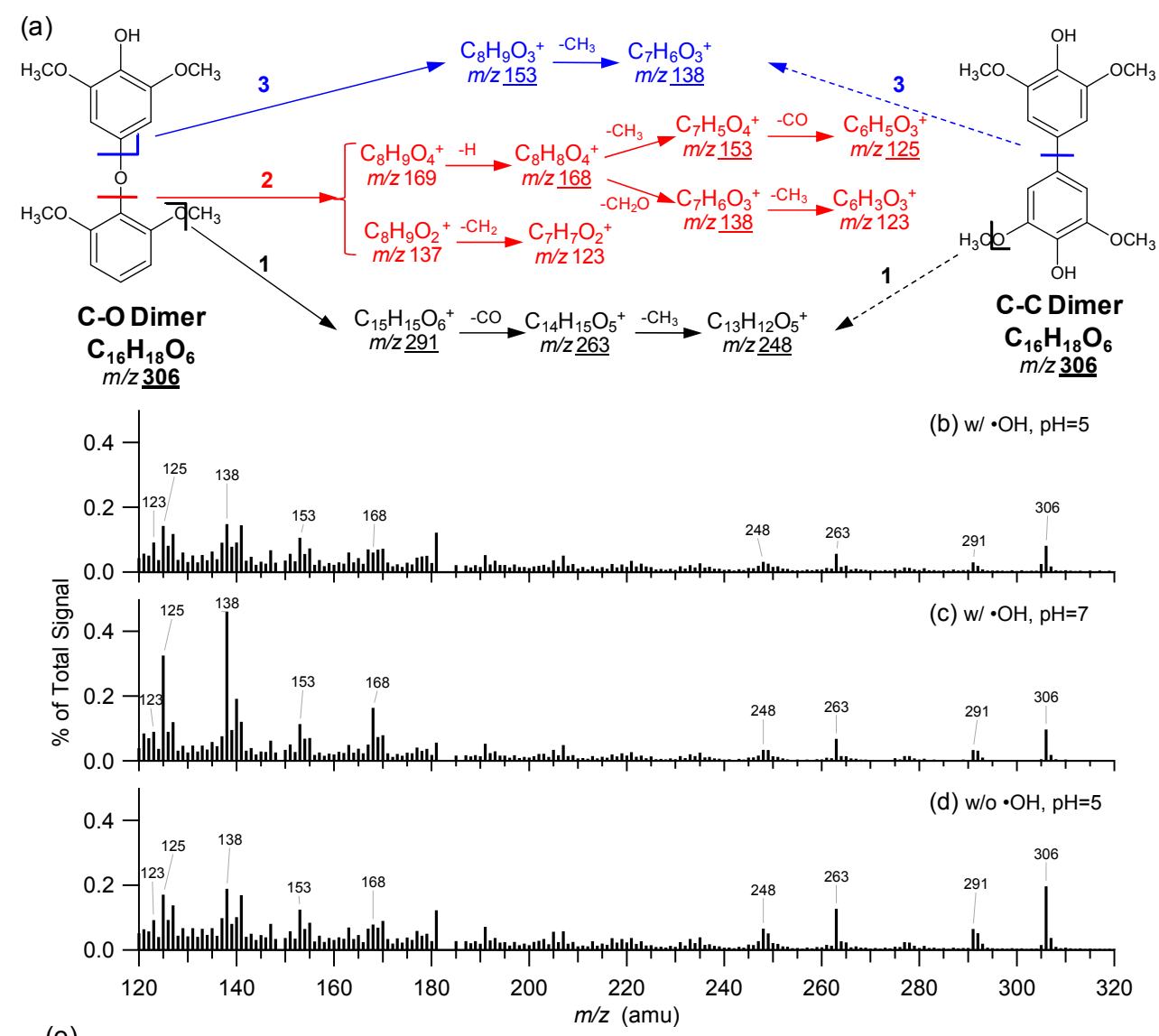

(e)

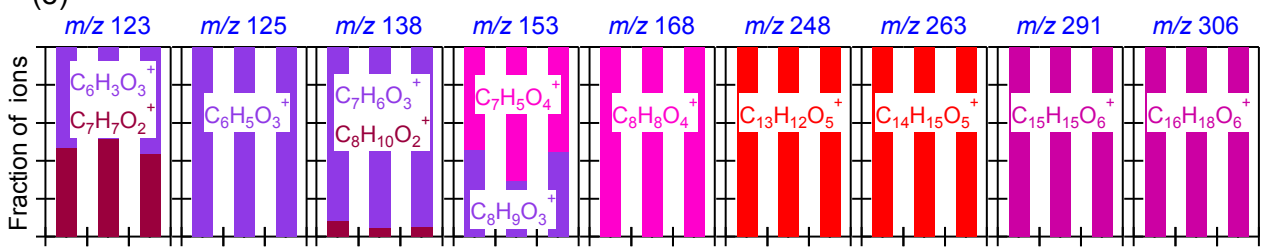

Fig. 7. (a) Postulated fragmentation mechanism and ions of syringol C-C and C-O dimers, (b-d) AMS mass spectra ( $m / z$ 120-320) of syringol SOA produced via aqueous-phase photolysis under different experimental conditions, (e) fraction of ions for $m / z$ 's which are significant in (b-d) and underscored in (a). Ions containing different number of $\mathrm{O}$ in (e) are shown in different colors.

was observed in irradiation of an aqueous solution containing much higher concentrations of phenol $(10 \mathrm{mM})$ and $\mathrm{H}_{2} \mathrm{O}_{2}$ (1 mM) compared to this study (Chang and Thompson, 2010). In contrast, we see ions showing that phenol has been hydroxylated to more oxygenated forms. For example, $\mathrm{C}_{6} \mathrm{H}_{6} \mathrm{O}_{2}^{+}(m / z 110)$, which could be the $\mathrm{M}^{+}$of hydroquinone and catechol, is a significant peak in the phenol SOA spectrum (Fig. 8a and c). These two compounds, as well as the meta-dihydroxy isomer, are formed from phenol via efficient $\mathrm{OH}$ addition to the aromatic ring in the aqueous phase (e.g., Albarran and Schuler, 2007; Bonin et al., 2007).

A more detailed mechanism of hydroxylation is illustrated in Fig. 5. It shows the addition of $\mathrm{OH}$ to the ring as an initial step followed by the formation of most abundant ringretaining product of hydroxylated phenol from $\mathrm{H}$-atom ab- straction involving $\mathrm{O}_{2}$ (Fig. 5). The OH-phenol adduct may also undergo unimolecular elimination of $\mathrm{H}_{2} \mathrm{O}$ to form a phenoxy radical (Land and Ebert, 1967; Atkinson et al., 1992; Barzaghi and Herrmann, 2002; Olariu et al., 2002), which leads to the formation of oligomers (Fig. 5). Similar hydroxylation reactions undoubtedly also occur with guaiacol and syringol, both before and after dimerization/oligomerization, and contribute to the large degree of oxidation of the phenolic SOA (Table 1).

\subsection{Observation of phenolic SOA signatures in ambient aerosols}

To examine whether ambient particles show evidence of SOA formed from the aqueous processing of phenols, a $\mathrm{PM}_{2.5}$ 


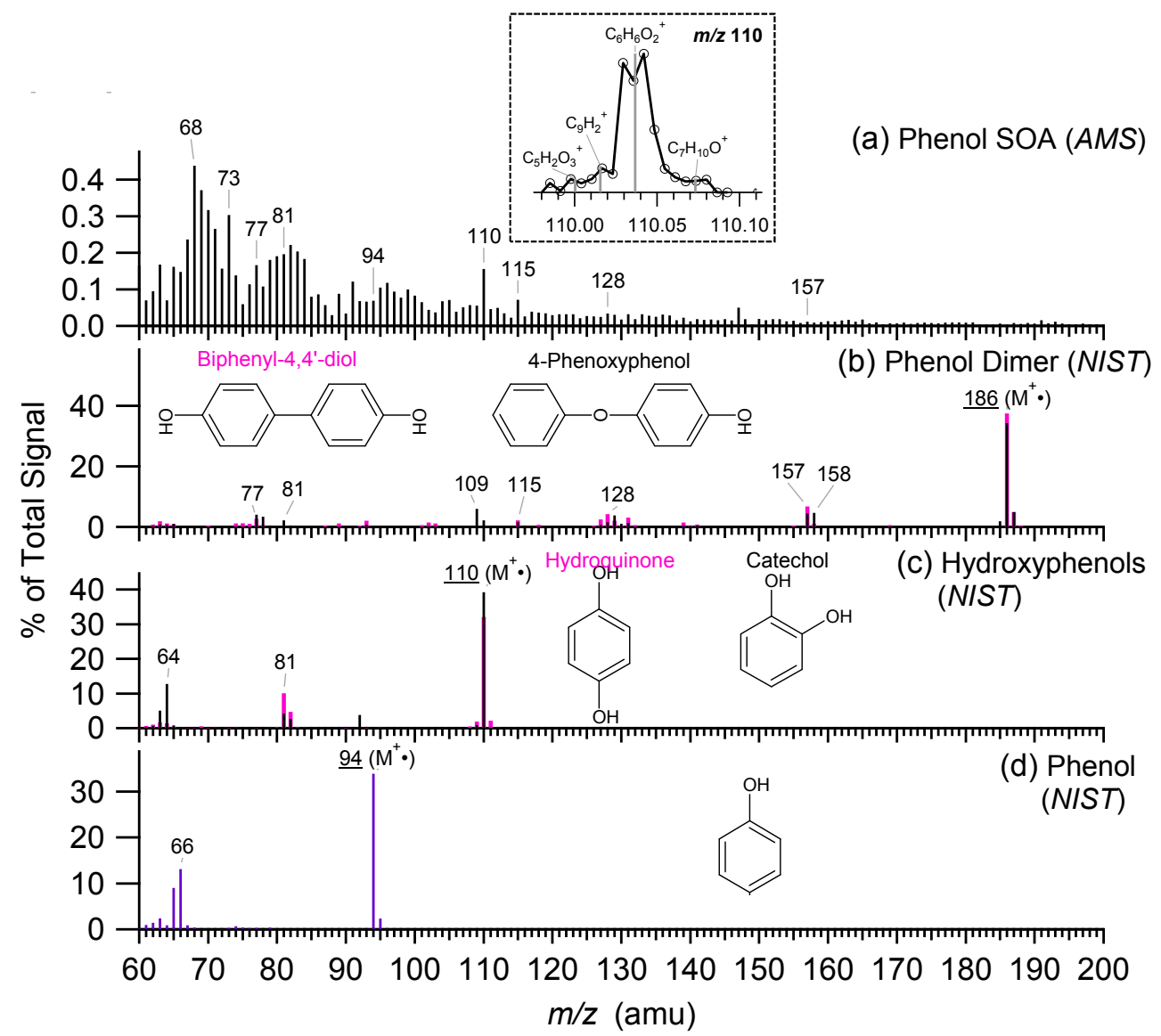

Fig. 8. Comparisons of (a) the AMS spectrum of phenol SOA produced via aqueous phase photoreactions (w/OH, pH=5) with the NIST mass spectra of (b) the C-C coupled (biphenyl-4,4'-diol) and C-O coupled (4-phenoxyphenol) dimers of phenol, (c) hydroquinone and catechol, and (d) phenol. The molecular ions $\left(\mathrm{M}^{+}\right)$are marked and the molecular structures are shown. The inset in (a) shows the high resolution spectrum of phenol SOA at $m / z 110$, which is primarily $\mathrm{C}_{6} \mathrm{H}_{6} \mathrm{O}_{2}^{+}-$the molecular ions of hydroxyphenols.

sample collected after a fog event on 9 January 2006 in Fresno, California was extracted in water, aerosolized with an atomizer, and analyzed using the same method discussed in Sun and Zhang (2010). This PM sample likely contains significant contribution from wood combustion as its HRMS (Fig. 9a) shows elevated signals at $m / z 60\left(\mathrm{C}_{2} \mathrm{H}_{4} \mathrm{O}_{2}^{+}\right)$and $73\left(\mathrm{C}_{3} \mathrm{H}_{5} \mathrm{O}_{2}^{+}\right)$, which are the AMS markers for wood burning (Alfarra et al., 2007; Aiken et al., 2009). Signature ions for syringol and guaiacol dimers, i.e., $\mathrm{C}_{16} \mathrm{H}_{18} \mathrm{O}_{6}^{+}(m / z$ 306) and $\mathrm{C}_{14} \mathrm{H}_{14} \mathrm{O}_{4}^{+}(m / z 246)$, respectively, are clearly observed (Fig. 9b-c), suggesting the presence of these compounds, which are probably formed via aqueous reactions either in fog droplets or deliquesced particles. Other major peaks of syringol and guaiacol SOA - e.g., $m / z 69\left(\mathrm{C}_{3} \mathrm{HO}_{2}^{+}\right.$, $\left.\mathrm{C}_{4} \mathrm{H}_{5} \mathrm{O}^{+}, \mathrm{C}_{5} \mathrm{H}_{9}^{+}\right), 263\left(\mathrm{C}_{14} \mathrm{H}_{15} \mathrm{O}_{5}^{+}\right)$, and $95\left(\mathrm{C}_{5} \mathrm{H}_{3} \mathrm{O}_{2}^{+}\right.$, $\left.\mathrm{C}_{6} \mathrm{H}_{7} \mathrm{O}^{+}\right)$- are observed as well, although it is possible that these ions were contributed by other organic species. Overall, these results suggest that aqueous-phase processing of phenolic compounds (e.g., from biomass burning emissions) may be an important pathway for SOA formation in atmo- sphere. In addition, the detection of phenol SOA signatures in ambient aerosol also suggest the mass spectra from our laboratory work may be used as a reference for SOA formed via aqueous processing of phenols.

\section{Conclusions and implications}

We have characterized the SOA products formed via aqueous-phase photochemical reactions of phenolic compounds. Elemental analysis of the HR-AMS spectra indicates that they are highly oxidized. The $\mathrm{O} / \mathrm{C}$ ratios of the phenolic SOA material are in the range of $0.80-1.06$, which are similar to the values observed for low volatility, aged regional SOA in ambient air.

Compared to the SOA formed in solutions exposed only to simulated sunlight, the SOA formed from a given phenolic precursor in the presence of $\mathrm{OH}$ showed a higher $\mathrm{O} / \mathrm{C}$ ratio and a higher yield of oxalate. Formation of oxalate and other small organic acids is ubiquitous though they account 

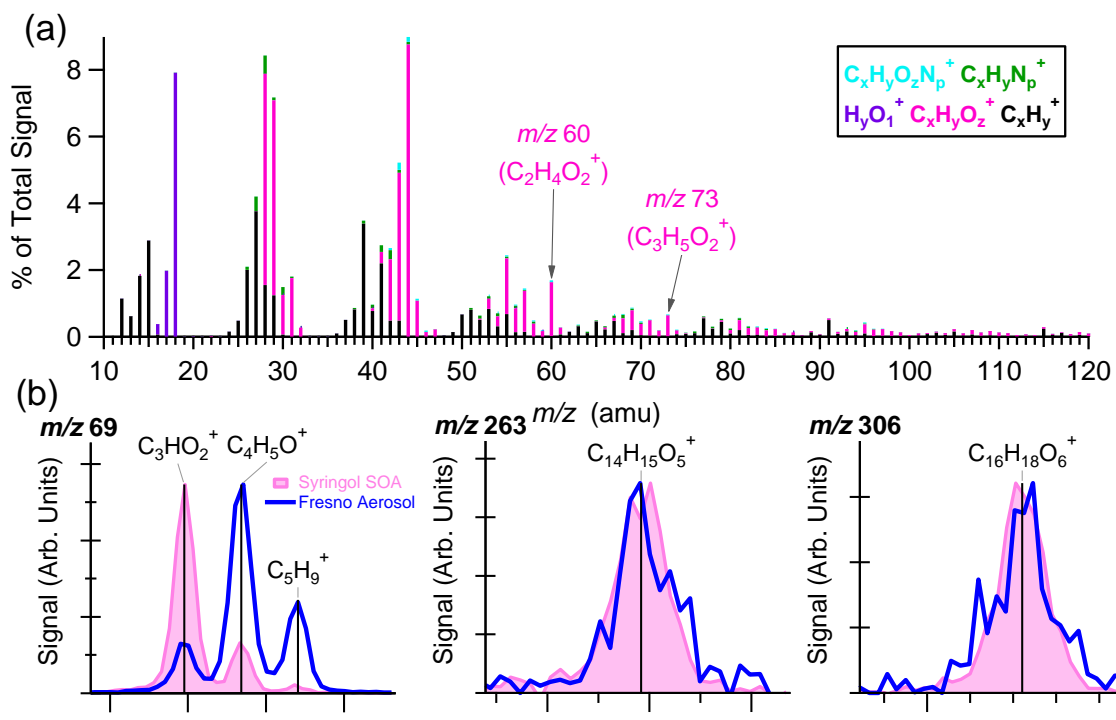

(c)
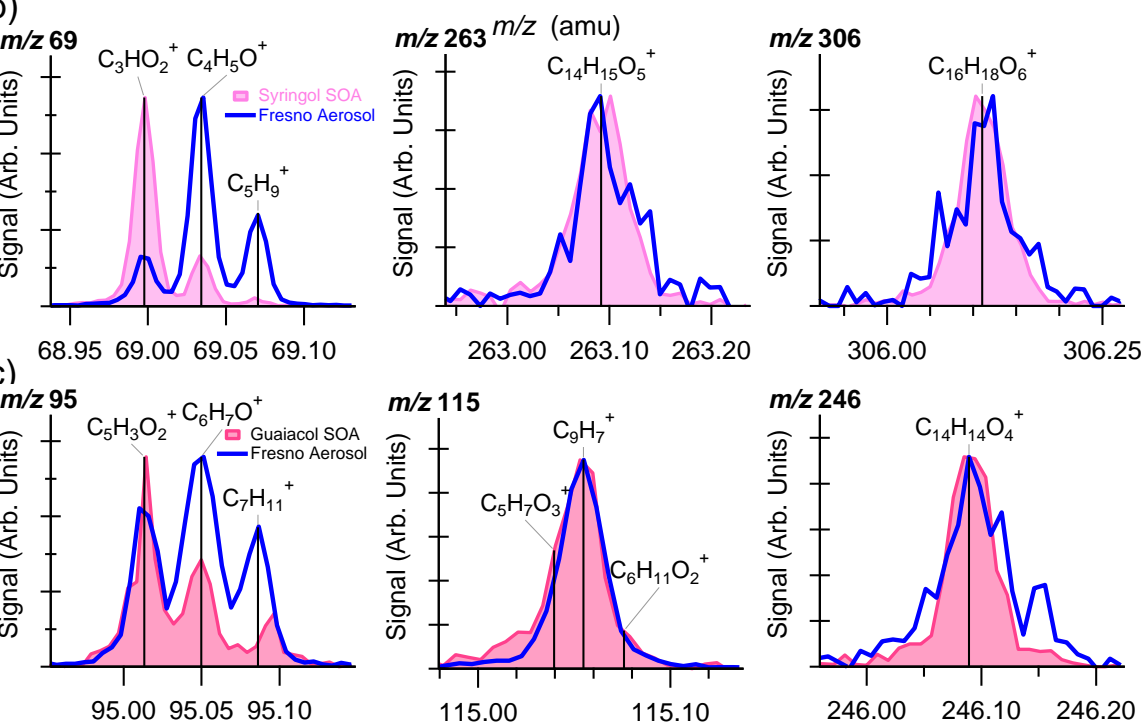

Fig. 9. (a) Categorized HRMS of Fresno aerosol collected on 9 January 2006 after a fog event $\left(\mathrm{H}_{2} \mathrm{O}^{+}=\mathrm{CO}_{2}^{+}\right.$, and $\mathrm{CO}^{+}=0.8 \mathrm{CO}_{2}^{+}$based on Sun et al., 2010); (b) and (c) comparison of AMS raw mass spectra of selected $\mathrm{m} / \mathrm{z}$ 's between Fresno aerosol and aqueous phase SOA produced from syringol and guaiacol, respectively.

for only a small fraction $(<10 \%)$ of the total SOA mass. A considerable fraction of the SOA products formed from guaiacol and syringol are dimers and higher oligomers, formed via coupling of phenoxy radicals. The phenol SOA spectrum shows little evidence of dimers but significant amounts of more oxygenated species formed via hydroxylation of the aromatic ring. We identified $\mathrm{C}_{16} \mathrm{H}_{18} \mathrm{O}_{6}^{+}(m / z$ 306) and $\mathrm{C}_{14} \mathrm{H}_{14} \mathrm{O}_{4}^{+}(m / z$ 246) as two mass spectral signatures for syringol and guaiacol dimers, respectively; both ions were observed in ambient aerosol influenced significantly by wood burning and had been subjected to fog processing.

Our results indicate that fog/cloud processing of phenolic compounds may represent an important pathway for the production of low-volatility, highly oxygenated materials, which may remain in the particle phase upon fog/cloud evaporation. Similar reactions likely occur in aqueous particles as well. We are currently working to determine the significance of aqueous reactions of phenols as a source of ambient SOA, but our initial estimates suggest this pathway is significant, especially in regions of wood combustion (Anastasio and Sun, 2010). Given that the SOA formed from aqueous reactions of phenolic compounds are both water soluble (Anastasio and Sun, 2010) and light absorbing (Gelencsér et al., 2003; Chang and Thompson, 2010), these reactions might significantly modify the chemical composition, size distribution, and properties of particles in certain regions, which in turn would influence the climate and human-health related effects of these aerosols.

Acknowledgements. This research was supported by the Office of Science (BER), US Department of Energy, Grant No. DEFG02-08ER64627, the California Agricultural Experiment Station (Project CA-D*-LAW-6403-RR), and the University of California, Sichuan University, and the China Scholarship Council through the 10+10 Alliance. We thank Prof. Jeff Collett (CSU) and Prof. Lynn Mazzoleni (MTU) for providing the Fresno aerosol sample and Prof. Kenneth Demerjian (SUNY-Albany) for sharing the IC and TOC analyser. We also thank Dr. Barbara Turpin and two anonymous reviewers for their constructive comments that helped improve this manuscript.

Edited by: M. C. Facchini 


\section{References}

Aiken, A. C., DeCarlo, P. F., and Jimenez, J. L.: Elemental analysis of organic species with electron ionization high-resolution mass spectrometry, Anal. Chem., 79, 8350-8358, 2007.

Aiken, A. C., DeCarlo, P. F., Kroll, J. H., et al.: O/C and OM/OC ratios of primary, secondary, and ambient organic aerosols with High-Resolution Time-of-Flight Aerosol Mass Spectrometry, Environ. Sci. Technol., 42, 4478-4485, 2008.

Aiken, A. C., Salcedo, D., Cubison, M. J., Huffman, J. A., DeCarlo, P. F., Ulbrich, I. M., Docherty, K. S., Sueper, D., Kimmel, J. R., Worsnop, D. R., Trimborn, A., Northway, M., Stone, E. A., Schauer, J. J., Volkamer, R. M., Fortner, E., de Foy, B., Wang, J., Laskin, A., Shutthanandan, V., Zheng, J., Zhang, R., Gaffney, J., Marley, N. A., Paredes-Miranda, G., Arnott, W. P., Molina, L. T., Sosa, G., and Jimenez, J. L.: Mexico City aerosol analysis during MILAGRO using high resolution aerosol mass spectrometry at the urban supersite (T0) - Part 1: Fine particle composition and organic source apportionment, Atmos. Chem. Phys., 9, 66336653, doi:10.5194/acp-9-6633-2009, 2009.

Albarran, G. and Schuler, R. H.: Hydroxyl Radical as a Probe of the Charge Distribution in Aromatics: Phenol, J. Phys. Chem. A, 111, 2507-2510, doi:10.1021/jp068736r, 2007.

Alfarra, M. R.: Insights into Atmospheric Organic Aerosols Using an Aerosol Mass Spectrometer, Chemical Engineering, University of Manchester, Manchester, 2004.

Alfarra, M. R., Prevot, A. S. H., Szidat, S., et al.: Identification of the mass spectral signature of organic aerosols from wood burning emissions, Environ. Sci. Technol., 41, 5770-5777, 2007.

Allan, J. D., Delia, A. E., Coe, H., et al.: A generalised method for the extraction of chemically resolved mass spectra from Aerodyne aerosol mass spectrometer data, J. Aerosol Sci., 35, 909922, 2004.

Altieri, K. E., Carlton, A. G., Lim, H. J., Turpin, B. J., and Seitzinger, S. P.: Evidence for oligomer formation in clouds: reactions of isoprene oxidation products, Environ. Sci. Technol., 40, 4956-4960, 2006.

Altieri, K. E., Seitzinger, S. P., Carlton, A. G., et al.: Oligomers formed through in-cloud methylglyoxal reactions: Chemical composition, properties, and mechanisms investigated by ultrahigh resolution FT-ICR mass spectrometry, Atmos. Environ., 42, 1476-1490, 2008.

Anastasio, C., Faust, B. C., and Rao, C. J.: Aromatic carbonyl compounds as aqueous-phase photochemical sources of hydrogen peroxide in acidic sulfate aerosols, fogs, and clouds 1. Non-phenolic methoxybenzaldehydes and methoxyacetophenones with reductants (phenols), Environ. Sci. Technol., 31, 218232, 1997.

Anastasio, C. and Sun, J.: Secondary organic aerosol (SOA) formation via aqueous-phase reactions of phenolic compounds, in preparation, 2010.

Atkinson, R., Aschmann, S. M., and Arey, J.: Reactions of hydroxyl and nitrogen trioxide radicals with phenol, cresols, and 2nitrophenol at 296 \pm 2 K, Environ. Sci. Technol., 26, 1397-1403, doi:10.1021/es00031a018, 1992.

Barzaghi, P. and Herrmann, H.: A mechanistic study of the oxidation of phenol by $\mathrm{OH} / \mathrm{NO}_{2} / \mathrm{NO}_{3}$ in aqueous solution, Phys. Chem. Chem. Phys., 4, 3669-3675, doi:10.1039/b201652d, 2002.
Blando, J. D. and Turpin, B. J.: Secondary organic aerosol formation in cloud and fog droplets: a literature evaluation of plausibility, Atmos. Environ., 34, 1623-1632, 2000.

Bonin, J., Janik, I., Janik, D., and Bartels, D. M.: Reaction of the hydroxyl radical with phenol in water up to supercritical conditions, J. Phys. Chem. A, 111, 1869-1878, doi:10.1021/jp0665325, 2007.

Buxton, G. V., Malone, T. N., and Salmon, G. A.: Oxidation of glyoxal initiated by $\mathrm{OH}$ in oxygenated aqueous solution, J. Chem. Soc., Faraday Trans., 93, 2889-2891, 1997.

Canagaratna, M., Jayne, J., Jimenez, J. L., et al.: Chemical and Microphysical Characterization of Aerosols via Aerosol Mass Spectrometry, Mass Spectrom. Rev., 26, 185-222, 2007.

Carlton, A. G., Turpin, B. J., Lim, H.-J., Altieri, K. E., and Seitzinger, S.: Link between isoprene and secondary organic aerosol (SOA): Pyruvic acid oxidation yields low volatility organic acids in clouds, Geophys. Res. Lett., 33, L06822, doi:06810.01029/02005GL025374, 2006.

Carlton, A. G., Turpin, B. J., Altieri, K. E., et al.: Atmospheric oxalic acid and SOA production from glyoxal: Results of aqueous photooxidation experiments, Atmos. Environ., 41, 7588-7602, 2007.

Chang, J. L. and Thompson, J. E.: Characterization of colored products formed during irradiation of aqueous solutions containing $\mathrm{H}_{2} \mathrm{O}_{2}$ and phenolic compounds, Atmos. Environ., 44, 541-551, 2010 .

de Gouw, J. and Jimenez, J. L.: Organic aerosols in the Earth's atmosphere, Environ. Sci. Technol., 43, 7614-7618, doi:10.1021/es9006004, 2009.

DeCarlo, P. F., Kimmel, J. R., Trimborn, A., et al.: FieldDeployable, High-Resolution, Time-of-Flight Aerosol Mass Spectrometer, Anal. Chem., 78, 8281-8289, 2006.

Dzepina, K., Arey, J., Marr, L. C., et al.: Detection of particlephase polycyclic aromatic hydrocarbons in Mexico City using an aerosol mass spectrometer, Int. J. Mass Spectrom., 263, 152170, 2007.

Ervens, B., George, C., Williams, J. E., et al.: CAPRAM 2.4 (MODAC mechanism): An extended and condensed tropospheric aqueous phase mechanism and its application, J. Geophys. Res., 108 (D14), 4426, doi:10.1029/2002jd002202, 2003.

Ervens, B., Feingold, G., Frost, G. J., and Kreidenweis, S. M.: A modeling study of aqueous production of dicarboxylic acids: 1. Chemical pathways and speciated organic mass production, J. Geophys. Res.-Atmos., 109, D15205, doi:10.1029/12003JD004387, 2004.

Feigenbrugel, V., Le Calvé, S., Mirabel, P., and Louis, F.: Henry's law constant measurements for phenol, o-, m-, and p-cresol as a function of temperature, Atmos. Environ., 38, 5577-5588, 2004.

Gelencsér, A., Hoffer, A., Kiss, G., et al.: In-situ Formation of Light-Absorbing Organic Matter in Cloud Water, J. Atmos. Chem., 45, 25-33, 2003.

Graber, E. R. and Rudich, Y.: Atmospheric HULIS: How humiclike are they? A comprehensive and critical review, Atmos. Chem. Phys., 6, 729-753, doi:10.5194/acp-6-729-2006, 2006.

Guo, X. X. and Brimblecombe, P.: Henry's law constants of phenol and mononitrophenols in water and aqueous sulfuric acid, Chemosphere, 68, 436-444, 2007. 
Guzmán, M. I., Colussi, A. J., and Hoffmann, M. R.: Photoinduced oligomerization of aqueous pyruvic acid, J. Phys. Chem. A, 110, 3619-3626, doi:10.1021/jp056097z, 2006.

Hallquist, M., Wenger, J. C., Baltensperger, U., Rudich, Y., Simpson, D., Claeys, M., Dommen, J., Donahue, N. M., George, C., Goldstein, A. H., Hamilton, J. F., Herrmann, H., Hoffmann, T., Iinuma, Y., Jang, M., Jenkin, M. E., Jimenez, J. L., Kiendler-Scharr, A., Maenhaut, W., McFiggans, G., Mentel, Th. F., Monod, A., Prévôt, A. S. H., Seinfeld, J. H., Surratt, J. D., Szmigielski, R., and Wildt, J.: The formation, properties and impact of secondary organic aerosol: current and emerging issues, Atmos. Chem. Phys., 9, 5155-5236, doi:10.5194/acp-95155-2009, 2009.

Hawthorne, S. B., Miller, D. J., Langenfeld, J. J., and Krieger, M. S.: $\mathrm{PM}_{10}$ high-volume collection and quantitation of semi- and nonvolatile phenols, methoxylated phenols, alkanes, and polycyclic aromatic hydrocarbons from winter urban air and their relationship to wood smoke emissions, Environ. Sci. Technol., 26, 2251-2262, doi:10.1021/es00035a026, 1992.

Jimenez, J. L., Canagaratna, M. R., Donahue, N. M., et al.: Evolution of organic aerosols in the atmosphere, Science, 326, 15251529, doi:10.1126/science.1180353, 2009.

Kanakidou, M., Seinfeld, J. H., Pandis, S. N., Barnes, I., Dentener, F. J., Facchini, M. C., Van Dingenen, R., Ervens, B., Nenes, A., Nielsen, C. J., Swietlicki, E., Putaud, J. P., Balkanski, Y., Fuzzi, S., Horth, J., Moortgat, G. K., Winterhalter, R., Myhre, C. E. L., Tsigaridis, K., Vignati, E., Stephanou, E. G., and Wilson, J.: Organic aerosol and global climate modelling: a review, Atmos. Chem. Phys., 5, 1053-1123, doi:10.5194/acp-5-1053-2005, 2005.

Kobayashi, S. and Higashimura, H.: Oxidative polymerization of phenols revisited, Prog. Polym. Sci., 28, 1015-1048, 2003.

Kroll, J. H. and Seinfeld, J. H.: Chemistry of secondary organic aerosol: Formation and evolution of low-volatility organics in the atmosphere, Atmos. Environ., 42, 3593-3624, 2008.

Kroll, J. H., Kessler, S. H., Smith, J. D., et al.: Changes to carbon oxidation state during the photochemical aging of organic aerosol, American Geophysical Union, Fall Meeting 2009, abstract \#A21H-07, San Francisco, 2009.

Land, E. J. and Ebert, M.: Pulse radiolysis studies of aqueous phenol. Water elimination from dihydroxycyclohexadienyl radicals to form phenoxyl, Trans. Faraday Soc., 63, 1181-1190, doi:10.1039/TF9676301181, 1967.

Leuenberger, C., Ligocki, M. P., and Pankow, J. F.: Trace organic compounds in rain. 4. Identities, concentrations, and scavenging mechanisms for phenols in urban air and rain, Environ. Sci. Technol., 19, 1053-1058, doi:10.1021/es00141a005, 1985.

Lim, H.-J., Carlton, A. G., and Turpin, B. J.: Isoprene forms secondary organic aerosol through cloud processing: model simulations, Environ. Sci. Technol., 39, 4441-4446, doi:10.1021/es048039h, 2005.

Lüttke, J., Scheer, V., Levsen, K., et al.: Occurrence and formation of nitrated phenols in and out of cloud, Atmos. Environ., 31, 2637-2648, 1997.

McLafferty, F. W. and Turecek, F.: Interpretation of Mass Spectra, University Science Books, Mill Valley, California, 1993.

NDRL (Notre Dame Radiation Laboratory), Chemical Kinetics Rate Constants: http://www.rcdc.nd.edu/Solnkin2/, access: April 2010, 2002.
Olariu, R. I., Klotz, B., Barnes, I., Becker, K. H., and Mocanu, R.: FT-IR study of the ring-retaining products from the reaction of $\mathrm{OH}$ radicals with phenol, o-, m-, and p-cresol, Atmos. Environ., 36, 3685-3697, 2002.

Perri, M. J., Seitzinger, S., and Turpin, B. J.: Secondary organic aerosol production from aqueous photooxidation of glycolaldehyde: Laboratory experiments, Atmos. Environ., 43, 1487-1497, 2009.

Sagebiel, J. C., Seiber, J. N., and Woodrow, J. E.: Comparison of headspace and gas-stripping methods for determining the Henry's law constant $(\mathrm{H})$ for organic compounds of low to intermediate H, Chemosphere, 25, 1763-1768, 1992.

Sagebiel, J. C. and Seiber, J. N.: Studies on the occurrence and distribution of wood smoke marker compounds in foggy atmospheres, Environ. Toxicol. Chem., 12, 813-822, 1993.

Saxena, P. and Hildemann, L. M.: Water-soluble organics in atmospheric particles: A critical review of the literature and application of thermodynamics to identify candidate compounds, J. Atmos. Chem., 24, 57-109, 1996.

Simoneit, B. R. T., Rogge, W. F., Mazurek, M. A., et al.: Lignin pyrolysis products, lignans, and resin acids as specific tracers of plant classes in emissions from biomass combustion, Environ. Sci. Technol., 27, 2533-2541, doi:10.1021/es00048a034, 1993.

Simoneit, B. R. T.: A review of biomarker compounds as source indicators and tracers for air pollution, Environ. Sci. Pollut. Res., 6, 159-169, 1999.

Sun, Y., Zhang, Q., Macdonald, A. M., Hayden, K., Li, S. M., Liggio, J., Liu, P. S. K., Anlauf, K. G., Leaitch, W. R., Steffen, A., Cubison, M., Worsnop, D. R., van Donkelaar, A., and Martin, R. V.: Size-resolved aerosol chemistry on Whistler Mountain, Canada with a high-resolution aerosol mass spectrometer during INTEX-B, Atmos. Chem. Phys., 9, 3095-3111, doi:10.5194/acp9-3095-2009, 2009.

Sun, Y. and Zhang, Q.: Characterization of water-soluble organic nitrogen in fog/cloud waters using a High Resolution Time-ofFlight Aerosol Mass Spectrometer, in preparation, 2010.

Tan, Y., Perri, M. J., Seitzinger, S. P., and Turpin, B. J.: Effects of precursor concentration and acidic sulfate in aqueous glyoxal-OH radical oxidation and implications for secondary organic aerosol, Environ. Sci. Technol., 43, 8105-8112, 10.1021/es901742f, 2009.

Turpin, B. J. and Lim, H. J.: Species contributions to $\mathrm{PM}_{2.5}$ mass concentrations: Revisiting common assumptions for estimating organic mass, Aerosol Sci. Tech., 35, 602-610, 2001.

Yao Liu, El Haddad, I., Scarfogliero, M., Nieto-Gligorovski, L., Temime-Roussel, B., Quivet, E., Marchand, N., PicquetVarrault, B., and Monod, A.: In-cloud processes of methacrolein under simulated conditions - Part 1: Aqueous phase photooxidation, Atmos. Chem. Phys., 9, 5093-5105, doi:10.5194/acp-95093-2009, 2009.

Zhang, Q., Alfarra, M. R., Worsnop, D. R., et al.: Deconvolution and quantification of hydrocarbon-like and oxygenated organic aerosols based on aerosol mass spectrometry, Environ. Sci. Technol., 39, 4938-4952, doi:4910.1021/es0485681, 2005a.

Zhang, Q., Worsnop, D. R., Canagaratna, M. R., and Jimenez, J. L.: Hydrocarbon-like and oxygenated organic aerosols in Pittsburgh: insights into sources and processes of organic aerosols, Atmos. Chem. Phys., 5, 3289-3311, doi:10.5194/acp-5-32892005, 2005b. 
Zhang, Q., Jimenez, J. L., Canagaratna, M. R., et al.: Ubiquity and dominance of oxygenated species in organic aerosols in anthropogenically-influenced northern hemisphere mid-latitudes, Geophys. Res. Lett., 34, L13801, doi:13810.11029/12007GL029979, 2007. 